\title{
Evaluating Environmental Service of Trisula Waterfall as Nature-based Tourism Attraction in Bromo Tengger Semeru National Park
}

\author{
Hamdani Dwi Prasetyo*, Luchman Hakim, Catur Retnaningdyah \\ ${ }^{2}$ Department of Biology, Faculty of Mathematics and Natural Sciences, University of Brawijaya, Malang, Indonesia
}

\begin{abstract}
Tourism activity in Trisula waterfall (locally called Coban Trisula) is growing significantly. The environmental management is important to perform the sustainable use of waterfall as tourism attraction. The aim of the research is to identify the ecosystem services of Trisula waterfall. In this study, three indices were calculated, namely Environmental Services Index, Hemeroby Index, and Naturalness index. This study found that the use of lands and natural resources in Trisula waterfall was low compared the upper and lower area. Lower and upper area was used for intensive agriculture and daily needs by local community. Those activities were influencing the environmental services of Trisula waterfall. Management towards sustainable use of Coban Trisula area was required. It is also important and should be able to promote security and satisfaction aspects for tourist. Anthropogenic activities such as plantation activities should be controlled by a persuasive approach to minimize disruption to the ecosystem. There are needs for environmental management to ensure the sustainability use of waterfall resources and its surrounding area.
\end{abstract}

Keywords: sustainable tourism, waterfall management, water conservation.

\section{INTRODUCTION}

Recently tourism grows significantly in East Java [1]. Tourism development in remotes area is one of the opportunities for local economic development [2]. Such tourism is especially important to support biodiversity conservation in these areas. In this activity, planner and manager of tourism are promoted to protect natural resources in these areas [2]. Many scholar has reported that conservation of natural resources is important aspect in tourism sustainability and development $[2,3]$.

Waterfall is one of the natural resources which are widely explored by tourism planner and manager as tourism destination [4]. Waterfall offer spectacular natural attraction which is provides numerous attractions for tourist, e.g. beauty landscape, waterfall phenomena, vegetation, fresh air and outdoor experiences. As an aquatic ecosystem, the waterfall has several functions such as provide clean water, control pollution, and supporting with some important chemical substances in the ecosystem. These functions will further support aquatic environmental services which consist of provisioning, regulating, cultural and supporting services [5].

\footnotetext{
${ }^{*}$ Correspondence address:

Hamdani Dwi Prasetyo

Email : hamdaniprasetyo@gmail.com

Address : Dept. of Biology, University of Brawijaya, Veteran Malang, Malang, 65145
}

For the purposes of sustainability, the management of waterfall is crucial. It is especially important to consider the impact of human in waterfall ecosystem. Some human activities in the ecosystem can alter and reduce environmental services of natural resources [6]. These can cause a decline of interest for waterfall tourism. Scholar point out that tourism development contributes to the environmental degradation. In the perspective of sustainable tourism planning and destination, designing proper environmental and resources usage is important [2]. In such case, evaluation of environmental status will contributes to the planning and decision making stages of the natural object for tourism purposes $[6,7]$.

Concerns to the environmental aspect in nature-based tourism destination are growing since there are numerous problems in tourism destination. Many nature-based tourism destinations have been reported under tourism activity pressure, including habitat degradation, pollution, wildlife reduction and extinction, exotic species introduction and invasion. Coban Trisula is one of waterfall in Bromo Tengger Semeru National Park, which area recently found and promoted as tourism destinations. In the situation where interest to visit nature is growing rapidly, managing water fall is important. As far, there is no environmental evaluation which is able to be used in management planning. The aim of the research is to describes the impact of human interaction to waterfall ecosystem area. 


\section{RESEARCH METHOD \\ Study Site}

Trisula Waterfall (Coban Trisula) located in Bromo Tengger Semeru National Park with altitude about 1.260-1.560 m above sea level. Field survey was set up at three area of Trisula Waterfall (Fig. 1). Geographically, these area were located at upper area $\left(8^{\circ} 0^{\prime} 2.9808^{\prime \prime} \mathrm{S}\right.$ $\left.112^{\circ} 52^{\prime} 14.43^{\prime \prime} \mathrm{E}\right)$, waterfall point $\left(8^{\circ} 0^{\prime} 24.8004^{\prime \prime} \mathrm{S}\right.$ $\left.112^{\circ} 51^{\prime} 40.7016^{\prime \prime} \mathrm{E}\right)$, and lower area $\left(7^{\circ}\right.$ 59'50.7336" S $112^{\circ} 52^{\prime} 23.8692^{\prime \prime}$ E). Trisula waterfall is part of the lower tropical mountains which are numerous plant species. Some notable species in waterfall area includes Engelhardia spicata, Acer laurinum, and Turpinia. Many species seems to be similr with the upper mountain forest [8].

As far, the waterfall has been visited by tourist, but the visitation number was still low. In the upper area, the water was used by local people in Ngadas for some purposes. According to National Park document related to national park area management, the Trisula waterfall is part of the National Park Resort Management with area about 5,222.75 Ha (Fig. 2).

\section{Methods}

Observation was set up at upper area of water fall, waterfall point and lower area of waterfall. Environmental aspect of Trisula waterfall was initiated by observing the landscape of forest area in which waterfall is part of the forest through Google Earth. From the viewpoint of Google Earth images, the visual examination was done to assess the landscape condition, including degree of forest covers, open space and indication of disturbance.

Some information was generated including plant density and dominancy, species endemism, list of exotic plant species and carbon stock. Environmental evaluation was continued with mapping some area of Trisula waterfall. Locations of some area were recorded by GPS Garmin 60CSx. The coordinates then applied in Google Earth and Quantum Geographic Information System (QGIS) version 2.14.4. Work Area of Bromo Tengger Semeru National Park were used to estimate and measured the wide area of Trisula waterfall which managed by RPTN Coban Trisula. Contour map in QGIS was used to determine the elevation for some area of Trisula waterfall. Stream image which showed in map was derived from Geospatial Information Agency (BIG).

From these images, ground check to the location was done. Land use changes were determined by maps and ground check information.

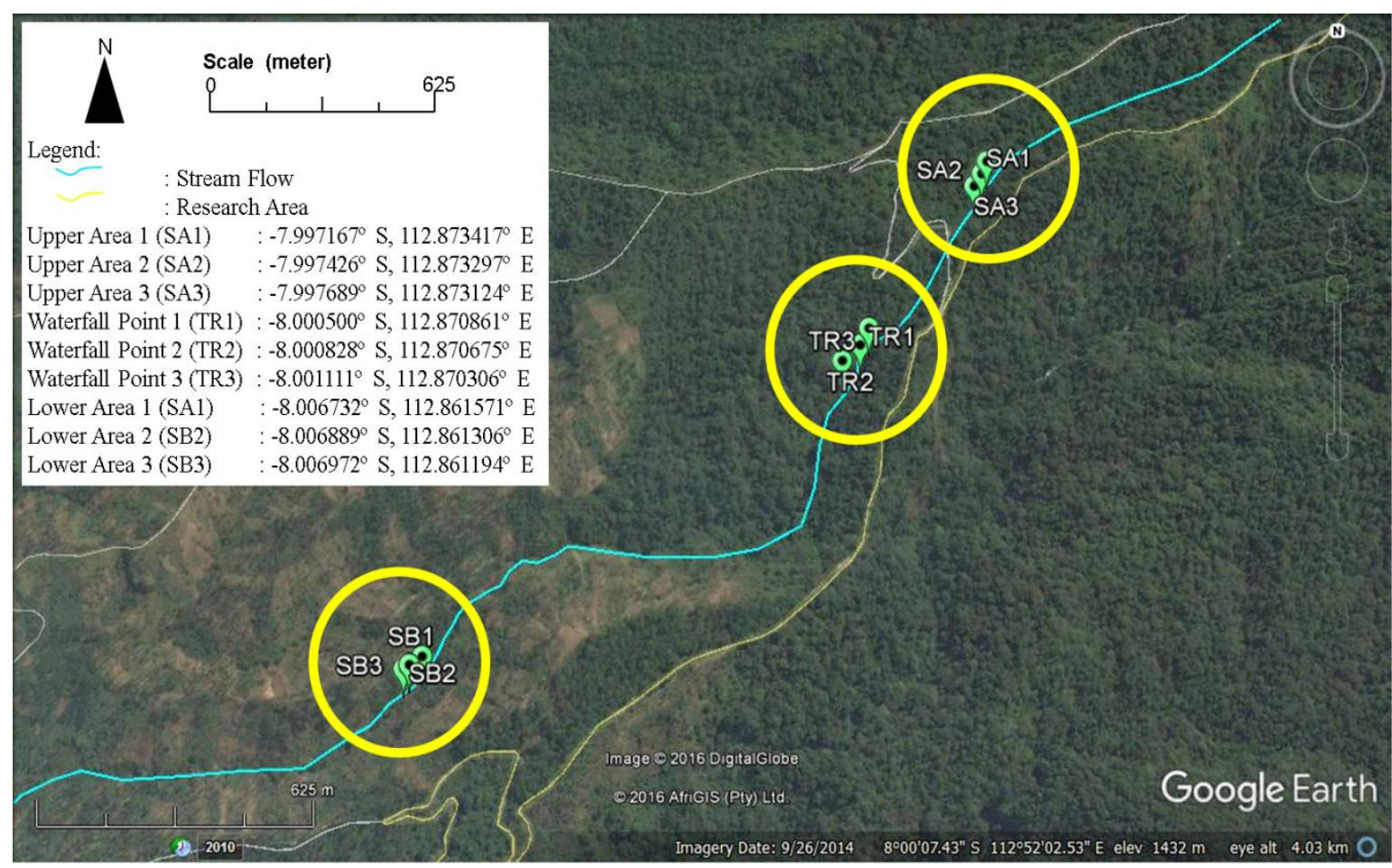

Figure 1. Research Areas of Trisula Waterfall 

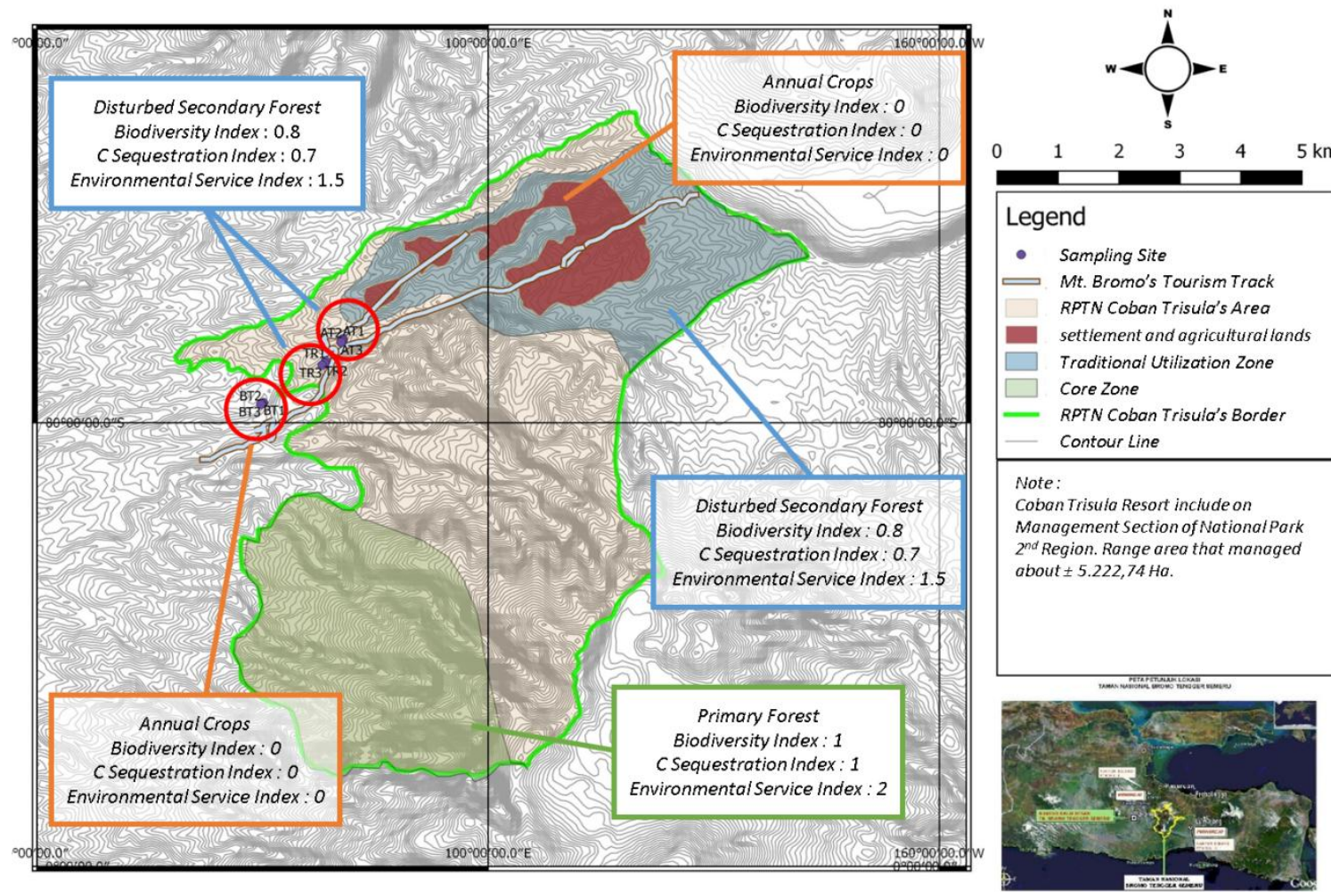

Figure 2. RPTN Trisula Region with Some Land Use Type

\section{Analysis of Environmental Service Index (ESI)}

Based on viewpoint focused in images for each plot was matched to land use criteria in Environmental Services Index which provided by Silvopastoral Project Baseline Survey [9]. Environmental Services Index was provided value of each land use. Environmental Services Index was included biodiversity index and carbon sequestration index.

\section{Analysis of Hemeroby Index and Naturalness Index}

Environmental Service was calculated using two Indices, namely Hemeroby index and Naturalness index. Hemeroby indices were applied to evaluate impact of anthropogenic factors to habitat quality in each observed stations. Score for Hemeroby indices was 0: Ahemerobe (natural), 1: Oligohemerobe (close to natural conditions), 2: Mesohemerobe (semi natural), 3: $\beta$-Hemerobe (far from natural), $4: \alpha-$ Hemerobe (further from natural), 5: Polyhemerobe (semi artificial), 6: Metahemerobe (artificial) [10].

Naturalness was used to assess the natural level of ecosystems. The application of the indices was based on direct visual observation. In such destination some aspect such as existence of endemic and exotic plant species, man-made buildings, pollutant, input energy, environmental conversion (i.e. mining), level of fragmentation, water dynamic and the general aspect of environmental dynamic was assessed [11]. The evaluation of each aspect was confirmed with the naturalness of environment as follow:

$$
\begin{array}{ll}
10 & =\text { Natural virgin } \\
9 & =\text { Natural } \\
8 & =\text { Sub Natural (changes not relevant) } \\
7 & =\text { Quasi-natural (natural, few relevant } \\
& \text { changes) } \\
6 & =\text { Semi-natural (natural, progressive) }
\end{array}
$$

\section{RESULT AND DISCUSSION}

\section{Land Uses Profiles}

The Coban Trisula Resort was consist of three zone, namely core zone $(1,355.73 \mathrm{Ha})$, wilderness zone $(2,576.57 \mathrm{Ha})$, and traditional uses zone $(1,290.44)$. The forest surrounding Trisula waterfall was lower mountain forest with numerous plant species. It is part of the core zone of national park. This area declared as an important conservation area to protect high level of biodiversity in Bromo Tengger Semeru forest. The wilderness zone was declared as protection area and limited nature-based tourism usage. In this area, the spot of waterfall found. This area 
especially rich in term of plant species, mammals and birds $[12,13,14]$.

The traditional use zone consists of rural area, in which it is dominated by orchards of Tenggerese from Ngadas People. In traditional uses zone there are Tenggerese settlement and agricultural lands. This area is known as Ngadas Village. Local people cultivate vegetables in sharp slope lands. In some forest patch in this area, local people collect wood for biomass.

From the Google map images, the area of Trisula waterfall was covered by tropical trees canopy with high intensity. The density of tree in Trisula waterfall was observed higher than in upper and lower area. These images confirm that there are significant forest cover structures. It is may occurs due to anthropogenic aspect. The farming practices in some patch of the forest lead some plant and canopy disappears. This mean, human contributes to the mountain forest ecosystem. Potentially, it is contributes to the decrease of mountain biodiversity, carbon storage and other environmental services $[9,15]$.

\section{Environmental Services Aspect}

The evaluation of environmental service confirm that the upper and Trisula waterfall point was classified as secondary forest with score 1.5 (Fig. 2) (Table 1).

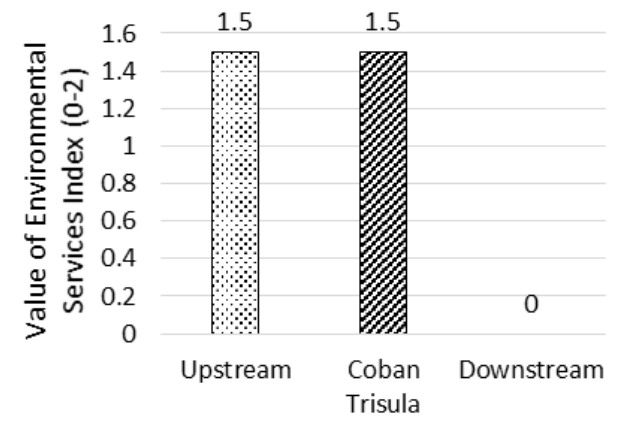

Figure 2. Environmental Service Index

Lower area of Trisula waterfall suffered from fragmentation habitat due to farming activity. It is includes farming potatoes, onion, carrots and other vegetables which has potential market value. Therefore, the value of such land use types was 0.0, in which land uses in annual crops farmlands category (Table 1). The disturbed secondary forest has biodiversity index 0.8 . Following the index value ranges, it is classified as high (range scale 0-1)[9].

Carbon sequestration index was 0.7 indicates that carbon stock in Trisula waterfall was better than in downstream area. It is relevant with the recent condition, in which the waterfall area is protected area while the lower area was consisted of farming lands. The conservation programs of area in surrounding waterfall contributes to the existence of numerous plant tree species which area able to store carbon $[16,17]$.

Table 1. Assessment of Land Use based on ESI indices

\begin{tabular}{cccc}
\hline $\begin{array}{c}\text { Location } \\
\text { (Land Use) }\end{array}$ & $\begin{array}{c}\text { Biodiversity } \\
\text { Index }\end{array}$ & $\begin{array}{c}\text { Carbon } \\
\text { Sequestration } \\
\text { Index }\end{array}$ & $\begin{array}{c}\text { Environmental } \\
\text { Service Index }\end{array}$ \\
\hline $\begin{array}{c}\text { Upper Area } \\
\text { (Disturbed } \\
\text { Secondary } \\
\text { Forest) }\end{array}$ & 0.8 & 0.7 & 1.5 \\
$\begin{array}{c}\text { Waterfall } \\
\text { Point }\end{array}$ & & & \\
$\begin{array}{c}\text { (Disturbed } \\
\text { Secondary } \\
\text { Forest) }\end{array}$ & 0.8 & 0.7 & 1.5 \\
Lower Area & & & \\
(Annual \\
Crops)
\end{tabular}

\section{Hemeroby and Naturalness Indices}

The monitoring of Trisula water fall and its surrounding area confirm that there is an ecosystem disturbance. Field observation found that the use of water in upper area of waterfall still low. It is shown by few land conversion except the establishment of water tank, post guard and rest area. The area was passed by forest road to Jarak ljo village. While there is few usages, this area is facing problems with waste from local dweller, especially from Ngadas and Jarak Ijo Villages. Based on Hemeroby index, this area classified as oligohemerobe because there are no human disturbance in this area. However, the management of area was needed to minimize the threats of waste and pollutant which area potentially disturb ecosystem [15].

Downstream of the river was farming land, in which many farmers manage the land to cultivate numerous vegetable. In many case, farmer used pesticides. According to Hemeroby index, it is classified as $\alpha$-Hemerobe. The application of pesticides and chemical fertilizer potentially contributes to the soil and water pollution. Therefore, promoting organic farming is important with some water management by phytoremediation agent [18].

Based on the Indonesia government law of Ministry of Environment and Forestry No. 82, 2001 has explaining that water use can be classified into four categories (Table 2) [19]. The 
evaluation result from this research showed that water in Trisula waterfall categorized as water quality in score 3. Water in downstream area can be classified in score 2 because there are farming activity.

Table 2. The Use of Water based on the Human Activity

\begin{tabular}{|c|c|c|}
\hline Water Usage & Score & Human Activity \\
\hline None & 4 & For drinking \\
\hline Light usage & 3 & Tourism and daily needs \\
\hline Fair usage & 2 & $\begin{array}{c}\text { Freshwater fish pond, livestock, } \\
\text { agriculture }\end{array}$ \\
\hline Moderate usage & 1 & Industrial, mining \\
\hline
\end{tabular}

Water in downstream area can be categorized in moderate usage because farming activity contributes to the water pollution. Impact of the farming in this area still has opportunities to increase the environment quality through organic farming and planting phytoremediator plant [18]. The naturalness index evaluation was addressed to inform the natural degree of waterfall. In the upper stream of water fall, indigenous plant such as Albizia lophanta, Geranium sp., Gonostegia sp., Elephantopus scaber and Equisetum sp. was identified low. Non native plant species was found in low number but dominant, while exotic plant species not dominant. Some building was found in this area, including water tank, bridge and forest road. There are no pollutants found, both biodegradable and non-degradable. The management of water consumption in this area was simple, water just collected in water tank and distributed to the settlement area. There are no fragmentation habitat was found, and therefore quantitatively the habitat degradation was low. The condition of Trisula waterfall can be classified in quasi natural, in which water poor to meet the ideal condition as an impact of deforestation < 50\% [20]. In fact, there are no deforestation, and it is possible because it seems to be related to natural process.

Water condition in Trisula waterfall is classified into sub natural. Area surround waterfall is habitat for numerous local plants. Number of exotic plant species was low. Forest road was found but less used. There is pollution identified. There is no input energy and land conversion was found. The use of water for daily life not found. Therefore, this area can be classified as natural area with fewer disturbances [11].

\section{CONCLUSION}

The environmental status of Trisula waterfall can be said good. There area some evidence of unsustainable land uses in upper and downstream area of water fall due to agricultural uses of land. These area strictly should be controlled systematically with the objective is achieving sustainable uses of resources. Revegetation will support the provision of environmental services be better. Moreover, anthropogenic activity can be controlled by a persuasive approach to minimize disruption to the ecosystem. In the tourist activity in Coban Trisula ecosystem, the lack of facilities and management of ecosystems is less likely to cause interest in low traffic. Therefore, improvement of facilities and proper management is essential to the provision of cultural services can be met properly.

\section{ACKNOWLEDGEMENT}

The first author would like to acknowledge the support from the Indonesian Endowment Fund (LPDP), the Indonesian Ministry of Finance, and all of colleague and staff Ecology and Animal Diversity Laboratory, University of Brawijaya.

\section{REFERENCES}

[1] Statistic Indonesia. 2016. Tourism Statistics of East Java 2016. Statistic Centre of East Java. Surabaya.

[2] Hakim, L. 2008. Planning for nature-based tourism in East Java: Recent status of biodiversity, conservation, and its implication for sustainable tourism. Asean Journal on Hospitality and Tourism 7(2), 155-167.

[3] Farhan, H. and K. Anwar. 2016. The tourism development strategy based in rural and local wisdom. Journal of Sustainable Development 9(3), 170-181.

[4] Rohman, A.N., Sudarmiatin and W. Wibowo. 2016. The implementation of tourism education for Nganjuk Community in empowerment efforts for Sedudo waterfall tourism attractions. IOSR Journal of Business and Management 18(5), 83-91.

[5] Aylward, B., J. Bandyopadhyay, J.C. Belausteguigotia, P. Borkey, A.Z. Cassar, L. Meadors, L. Saade, M. Siebentritt, R. Stein, S. Tognetti and C. Tortajada. 2005. Freshwater ecosystem services. Ecosystems and Human Well-Being: Policy Responses 3, 213256. 
[6] De Groot, R.S. 1992. Functions of nature: evaluation of nature in environmental planning, management and decision making. Wolters-Noordhoff BV. Amsterdam.

[7] Hakim, L., Retnaningdyah, C. and Mukhzayadah. 2014. Ecological and social evaluation of coastal tourism destination development: a case study of Balekambang, East Java. Journal of Indonesian Tourism and Development Studies 2(1), 26-32.

[8] Hakim, L. and H. Miyakawa. 2013. Plant trees species for restoration program in Ranupani, Bromo Tengger Semeru National Park Indonesia. Biodiversity Journal 4(3), 387-394.

[9] Pagiola, S., J.H. Rosés and J.F. González. 2016. Evaluation of the permanence of land use change induced by payments for Environmental Services in Quindío, Colombia. PLoS ONE 11(3), 1-18.

[10] Steinhardt, U., F. Herzog, A. Lausch, E. Müller and S. Lehmann. 1999. The hemeroby index for landscape monitoring and evaluation. In: Hyatt, D.E., R. Lenz and Y.A. Pykh (Eds). Environmental indices systems analysis approach. Advances in Sustainable Development. Proceedings of $1^{\text {st }}$ International Conference On Environmental Indices Systems Analysis Approach (INDEX-97), St. Petersburg, Russia, July 711, 1997. EOLSS. Oxford. 237-254.

[11] Machado, A. 2004. An index of naturalness. Journal for Nature Conservation 12(2), 95110.

[12] Syarifuddin, A. 2011. Identifikasi plasma nutfah vegetasi hutan alam Resort Trisula Taman Nasional Bromo Tengger Semeru (TNBTS). GAMMA 6, 77-94.

[13] Subarkah, M.H., N.B. Wawandono, S. Pudyatmoko, Subeno, S. Nurvianto and A. Budiman. 2011. Javan leaf monkey (Trachypithecus auratus) movement in a fragmented habitat, at Bromo Tengger Semeru National Park, East Java, Indonesia. Jurnal Biologi Indonesia 7, 213-220.

[14] Iqbal, K, Z.P. Gama and B. Yanuwiadi. 2015. Spatial distribution of birds in Coban Trisula, Bromo Tengger Semeru National Park. Proceeding of $6^{\text {th }}$ International Conference on Global Resource Conservation 6(1), 2630.

[15] Foley, J.A., R. Defries, G.P. Asner, C. Barford, G. Bonan, S.R. Carpenter and P.K. Snyder. 2005. Global Consequences of Land Use. Science 309, 570-574.
[16] Oren, R., D.S. Ellsworth, K.H. Johnsen, N. Phillips, B.E. Ewers, Maier and G.G. Katul. 2001. Soil fertility limits carbon sequestration by forest ecosystems in a CO2-enriched atmosphere. Nature 411 (6836), 469-472.

[17] Smith, P. 2004. Carbon sequestration in croplands: the potential in Europe and the global context. European Journal of Agronomy 20(3), 229-236.

[18] Prasetyo, H.D. and C. Retnaningdyah. 2013. Peningkatan kualitas air irigasi akibat penanaman vegetasi riparian dari hidromakrofita lokal selama 50 Hari. Biotropika 1, 149-153.

[19] Center for Environmental Impact Control Facilities (PUSARPEDAL). 2011. Assessment Report of Water Quality Criteria for attachment PP. No. 82 of 2001 on water quality management and control of water pollution. Ministry of Environment. Jakarta.

[20] Sweeney, B.W., T.L. Bott, J.K. Jackson, L.A. Kaplan, J.D. Newbold, L.J. Standley, W.C. Hession and R.J. Horwitz. 2004. Riparian deforestation, stream narrowing, and loss of stream ecosystem services. Proceedings of the National Academy of Sciences of the United States of America. 101(39), 1413214137. 